\title{
Unraveling the mystery of genetics and male infertility
}

Taking 13 years to complete, the Human Genome Project sequenced the entire euchromatic human genome. The accomplishment was hoped to offer solutions to many of man's most befuddling medical conditions, male infertility a prime example. What was discovered, however, was the tip of the iceberg. The sequence of base pairs only begins to shed light on the complex interplay between pre-translational, translational, and related factors that determine fertility potential.

This focused series of Translational Andrology and Urology explores our current understanding of the genetic causes and management of male infertility. Beginning with reviews of the basic genetic etiologies and relevant tests, this series then delves into well-known causes of male infertility including $\mathrm{Y}$ chromosome copy number variations, $\mathrm{Y}$ chromosome microdeletions, cystic fibrosis transmembrane conductance regulator $(C F T R)$ gene mutations, and hypogonadotropic hypogonadism. A novel review collates the available literature on nutrigenomics, detailing the interplay between diet, genetic makeup, and fecundity.

The latter half of this series focuses on management options for the above-mentioned and other genetic etiologies of male infertility. Two articles on Y chromosome microdeletions detail sperm retrieval techniques and assisted reproductive outcomes. Two additional reviews address sperm retrieval techniques and success rates for Klinefelter's syndrome and CFTR mutations. Equally as important, a special review discusses genetic counseling recommendations for men with known and unknown causes of infertility. The last article looks to the future, exploring research on the verge of bettering our understanding of genetic causes of male infertility.

On behalf of myself and my co-editor, Dr. Keith A. Jarvi, we would like to thank the editors and copyediting staff at Translational Andrology and Urology for their tireless efforts guiding this special edition from concept to final form. And we would be remiss without offering our sincerest thanks to our review article authors for their efforts in summarizing the available literature on these important topics, even during these trying times.

We all are living in a constant state of flux related to the ongoing COVID pandemic-from social isolation to implications on clinical practice to rapid advancements in medical research. Many relevant publications start with: "By the time you are reading this, much will have changed." As the reviews in this special edition will show, we are primed for similar changes in understanding the genetics of male infertility. We hope that by the time you are reading this, the mystery will continue to unravel.

\section{Acknowledgments}

Funding: None.

\section{Footnote}

Provenance and Peer Review: This article was commissioned by the editorial office, Translational Andrology and Urology for the series "Genetic Causes and Management of Male Infertility". The article did not undergo external peer review.

Conflicts of Interest: Both authors have completed the ICMJE uniform disclosure form (available at http://dx.doi.org/10.21037/ tau-2019-gcmi-14). The series "Genetic Causes and Management of Male Infertility" was commissioned by the editorial office without any funding or sponsorship. KAJ and JB served as the unpaid Guest Editors of the series. The authors have no other conflicts of interest to declare.

Ethical Statement: The authors are accountable for all aspects of the work in ensuring that questions related to the accuracy or integrity of any part of the work are appropriately investigated and resolved.

Open Access Statement: This is an Open Access article distributed in accordance with the Creative Commons AttributionNonCommercial-NoDerivs 4.0 International License (CC BY-NC-ND 4.0), which permits the non-commercial replication and distribution of the article with the strict proviso that no changes or edits are made and the original work is properly cited (including 
links to both the formal publication through the relevant DOI and the license). See: https://creativecommons.org/licenses/by-nc$\mathrm{nd} / 4.0 \%$.

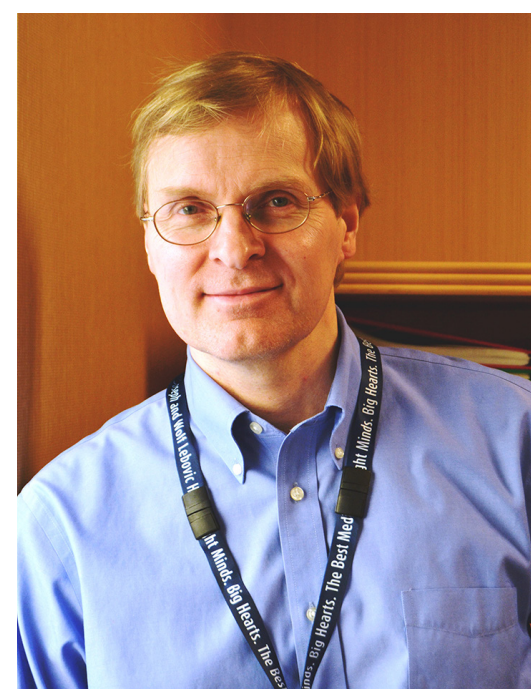

Keith A. Jarvi

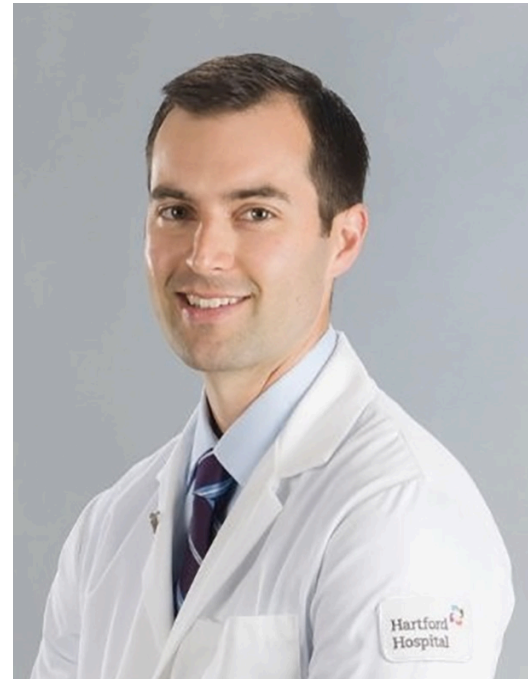

Jared M. Bieniek

Keith A. Jarvi

Division of Urology, Department of Surgery, Mount Sinai Hospital, University of Toronto, Toronto, ON, Canada.

Cite this article as: Jarvi KA, Bieniek JM. Unraveling the mystery of genetics and male infertility. Transl Androl Urol 2021;10(3):1352-1353. doi: 10.21037/tau-2019-gcmi-14 